\title{
$\mathrm{N}$-[4-(1H-Pyrazolo[3,4-B]pyrazin-6yl)-phenyl]-sulonamides and Their Use As Pharmaceuticals
}

\section{Benjamin Blass*}

Temple University School of Pharmacy, 3307 North Broad Street, Philadelphia, Pennsylvania 19140, United States

Title:

Patent Application Number: Priority Application:

Inventors:

Assignee Company:

Disease Area:

Summary:

Important Compound Classes:

\author{
N-[4-(1H-Pyrazolo[3,4-B]pyrazin-6yl)-phenyl]-sulonamides and Their Use As Pharmaceuticals

WO2013/041119A1 Publication date: March 28th, 2013 \\ EP2011/066220 Priority date: September 19th, 2011
}

Nazare, M.; Halland, N.; Schmidt, F.; Weiss, T.; Dietz, U.; Hofmeister, A.; Kujath, E.

Sanofi

Arthritis Biological Target: $\quad$ Serum/glucocorticoid regulated kinase 1(SGK-1)

The kinase superfamily remains an active area of interest to the pharmaceutical industry, as these enzymes are key players in a wide range of cellular functions. They regulate numerous cell functions, including, but not limited to, signal transduction, transcriptional regulation, cell motility, cell division, and apoptosis. The serum and glucocorticoid regulated kinases (SGKs) are a family of serine/threonine kinases that consists of three members, SGK-1, SGK-2, and SGK-3. SGK-1 has been implicated in the progression of osteoarthritis, one of the most common forms of degenerative joint disease. The pathological course of this disease includes destruction of articular cartilage, leaving the underlying bone tissue exposed. In advanced cases, joint replacement surgery may be required. Pathological changes in the associated ligaments and synovial membranes are also hallmarks of this condition. Recent studies have also demonstrated that changes in SGK-1 expression levels are associated with osteoarthritis. Specifically, comparative gene expression studies have established that this enzyme is expressed in degenerated/degenerating cartilage but not in healthy cartilage. Additional studies in mouse embryos have demonstrated that the presence of SGK-1 is directly associated with hypertrophy and degradation of cartilage tissue, suggesting that it causes or promotes the pathological progression of osteoarthritis. As such, inhibitors of SGK-1 may be useful for the treatment and prevention of osteoarthritis. The present patent application describes a series of phenylpyrazolopyrazine capable of inhibiting SGK-1 and their method of use for the treatment of degenerative joint disorders, degenerative cartilage changes, diabetes, cardiovascular diseases, fibrosis, inflammatory processes, pain, tumors, and cerebral infarctions.<smiles>[R17]c1cc(-c2cnc3c([R17])n[nH]c3n2)ccc1N[Se][3H]</smiles>

Definitions:

Ar is selected from the series consisting of phenyl and a 5- or 6-membered moncyclic aromatic heterocycle comprising 1, 2, or 3 identical or different ring heteroatoms selected from the series consisting of nitrogen, oxygen, and sulfur and bonded via a ring carbon atom, which are all unsubstituted or substituted by one or more identical or different substituents $\mathrm{R}^{10}$;

$n=1,2$ or 3 ;

$\mathrm{R}^{1}$ is selected from the series consisting of hydrogen, $-\mathrm{N}\left(\mathrm{R}^{11}\right)-\mathrm{R}^{12}, \mathrm{~N}\left(\mathrm{R}^{13}\right)-\mathrm{C}(\mathrm{O})-\mathrm{R}^{14}, \mathrm{~N}\left(\mathrm{R}^{13}\right)-\mathrm{SO}_{2}-\mathrm{R}^{15}$, $\mathrm{N}\left(\mathrm{R}^{13}\right)-\mathrm{C}(\mathrm{O}) \mathrm{NH}-\mathrm{R}^{14},-\mathrm{C}(\mathrm{O})-\mathrm{N}\left(\mathrm{R}^{16}\right)-\mathrm{R}^{17},-\mathrm{CN},-\mathrm{C}_{1}-\mathrm{C}_{4}$ alkyl, $-\mathrm{C}_{1}-\mathrm{C}_{4}-$ alkyl $_{-} \mathrm{OR}^{18}$;

$\mathrm{R}^{2}$ is selected from the series consisting of halogen, $-\mathrm{C}_{1}-\mathrm{C}_{4}$ alkyl, $-\mathrm{O}-\mathrm{C}_{1}-\mathrm{C}_{4}-$ alkyl, and $-\mathrm{CN}$;

$\mathrm{R}^{10}$ is selected from the series consisting of halogen, $-\mathrm{C}_{1}-\mathrm{C}_{4}-$ alkyl, $-\mathrm{C}_{3}-\mathrm{C}_{7}$ cycloalkyl, $-\mathrm{C}_{1}-\mathrm{C}_{4}$ alkyl $-\mathrm{C}_{3}-\mathrm{C}_{7}$ cycloalkyl, $-\mathrm{O}-\mathrm{C}_{1}-\mathrm{C}_{4}-$ alkyl, $-\mathrm{O}-\mathrm{C}_{3}-\mathrm{C}_{7}$ cycloalkyl, $-\mathrm{O}-\mathrm{C}_{1}-\mathrm{C}_{4}-$ alkyl $-\mathrm{C}_{3}-\mathrm{C}_{7}$ cycloalkyl, $-\mathrm{N}\left(\mathrm{R}^{19}\right)-\mathrm{R}^{20},-\mathrm{N}\left(\mathrm{R}^{21}\right)-\mathrm{N}\left(\mathrm{R}^{19}\right)-\mathrm{R}^{20}$, $-\mathrm{N}\left(\mathrm{R}^{21}\right)-\mathrm{C}(\mathrm{O})-\mathrm{R}^{22},-\mathrm{NO}_{2},-\mathrm{C}(\mathrm{O})-\mathrm{N}\left(\mathrm{R}^{23}\right)-\mathrm{R}^{24}$, and $-\mathrm{CN}$.

Two groups $\mathrm{R}^{10}$ bonded to adjacent ring carbon atoms in Ar, together with the carbon atoms carrying them, can form a 5 - to 8 -membered unsaturated ring, which comprises 0,1 , or 2 identical or different ring heteroatoms selected from the series consisting of nitrogen, oxygen, and sulfur and is unsubstituted or substituted by one or more identical or different substituents selected from the series consisting of halogen, $-\mathrm{C}_{1}-\mathrm{C}_{4}$ alkyl, $-\mathrm{O}-\mathrm{C}_{1}-\mathrm{C}_{4}-$ alkyl, and $-\mathrm{CN}$.

Received: September 29, 2013

Published: October 11, 2013 
$\mathrm{R}^{11}$ and $\mathrm{R}^{12}$ are independent of one another selected from the series consisting of hydrogen, $\left(\mathrm{C}_{1}-\mathrm{C}_{4}\right)-$ alkyl, $\left(\mathrm{C}_{3}-\mathrm{C}_{7}\right)$-cycloalkyl, $-\left(\mathrm{C}_{1}-\mathrm{C}_{4}\right)$-alkyl, and $-\left(\mathrm{C}_{3}-\mathrm{C}_{7}\right)-$ cycloalkyl, or $\mathrm{R}^{11}$ and $\mathrm{R}^{12}$, together with the nitrogen atom carrying them, form a monocyclic, 4- to 7-membered, saturated heterocycle, which, in addition to the nitrogen atom carrying $\mathrm{R}^{11}$ and $\mathrm{R}^{12}$, comprises 0 or 1 further ring heteroatom selected from the series consisting of nitrogen, oxygen, and sulfur and is unsubstituted or substituted by one or more identical or different substituents selected from the series consisting of fluorine and $\left(\mathrm{C}_{1}-\mathrm{C}_{4}\right)$-alkyl; $\mathrm{R}^{13}$ is selected from the series consisting of hydrogen, $\left(\mathrm{C}_{1}-\mathrm{C}_{4}\right)$-alkyl, and $\left(\mathrm{C}_{3}-\mathrm{C}_{7}\right)$-cycloalkyl;

$\mathrm{R}^{14}$ and $\mathrm{R}^{15}$ are independent of one another selected from the series consisting of $\left(\mathrm{C}_{1}-\mathrm{C}_{4}\right)$-alkyl, $\left(\mathrm{C}_{3}-\mathrm{C}_{7}\right)-$ cycloalkyl, $-\left(\mathrm{C}_{1}-\mathrm{C}_{4}\right)$-alkyl- $\left(\mathrm{C}_{3}-\mathrm{C}_{7}\right)$-cycloalkyl, phenyl, $-\left(\mathrm{C}_{1}-\mathrm{C}_{4}\right)$ alkyl-phenyl, Het, and $-\left(\mathrm{C}_{1}-\mathrm{C}_{4}\right)$-alkyl-Het, wherein phenyl and Het all are unsubstituted or substituted by one or more identical or different substituents $\mathrm{R}^{30}$;

$\mathrm{R}^{16}$ is selected from the series consisting of hydrogen, $\left(\mathrm{C}_{1}-\mathrm{C}_{4}\right)$-alkyl, and $\left(\mathrm{C}_{3}-\mathrm{C}_{7}\right)$-cycloalkyl;

$\mathrm{R}^{17}$ is selected from the series consisting of hydrogen, $\left(\mathrm{C}_{1}-\mathrm{C}_{4}\right)$-alkyl, $\left(\mathrm{C}_{3}-\mathrm{C}_{7}\right)-$ cycloalkyl, $-\left(\mathrm{C}_{1}-\mathrm{C}_{4}\right)-$ alkyl, $-\left(\mathrm{C}_{3}-\mathrm{C}_{7}\right)-$ cycloalkyl, phenyl, $-\left(\mathrm{C}_{1}-\mathrm{C}_{4}\right)$-alkyl-phenyl, Het, and $-\left(\mathrm{C}_{1}-\mathrm{C}_{4}\right)-$ alkyl-Het, wherein phenyl and Het all are unsubstituted or substituted by one or more identical or different substituents $\mathrm{R}^{30}$, or $\mathrm{R}^{16}$ and $\mathrm{R}^{17}$, together with the nitrogen atom carrying them, form a monocyclic, 4- to 7-membered, saturated heterocycle, which, in addition to the nitrogen atom carrying $\mathrm{R}^{16}$ and $\mathrm{R}^{17}$, comprises 0 or 1 further ring heteroatom selected from the series consisting of nitrogen, oxygen, and sulfur and is unsubstituted or substituted by one or more identical or different substituents selected from the series consisting of fluorine and $\left(\mathrm{C}_{1}-\mathrm{C}_{4}\right)$-alkyl;

$\mathrm{R}^{18}$ is selected from the series consisting of hydrogen and $\left(\mathrm{C}_{1}-\mathrm{C}_{4}\right)$-alkyl;

$\mathrm{R}^{19}$ is selected from the series consisting of hydrogen, $\left(\mathrm{C}_{1}-\mathrm{C}_{4}\right)$-alkyl, and $\left(\mathrm{C}_{3}-\mathrm{C}_{7}\right)$-cycloalkyl;

$\mathrm{R}^{20}$ is selected from the series consisting of hydrogen, $\left(\mathrm{C}_{1}-\mathrm{C}_{4}\right)-$ alkyl, $\left(\mathrm{C}_{3}-\mathrm{C}_{7}\right)-$ cycloalkyl, $-\left(\mathrm{C}_{1}-\mathrm{C}_{4}\right)-$ alkyl, $-\left(\mathrm{C}_{3}-\mathrm{C}_{7}\right)-$ cycloalkyl, phenyl, $-\left(\mathrm{C}_{1}-\mathrm{C}_{4}\right)$-alkyl-phenyl, Het, and $-\left(\mathrm{C}_{1}-\mathrm{C}_{4}\right)-$ alkyl-Het, wherein phenyl and Het all are unsubstituted or substituted by one or more identical or different substituents $\mathrm{R}^{30}$, or $\mathrm{R}^{19}$ and $\mathrm{R}^{20}$, together with the nitrogen atom carrying them, form a monocyclic, 4- to 7 -membered, saturated heterocycle, which, in addition to the nitrogen atom carrying $\mathrm{R}^{19}$ and $\mathrm{R}^{20}$, comprises 0 or 1 further ring heteroatom selected from the series consisting of nitrogen, oxygen, and sulfur and is unsubstituted or substituted by one or more identical or different substituents selected from the series consisting of fluorine and $\left(\mathrm{C}_{1}-\mathrm{C}_{4}\right)$-alkyl;

$\mathrm{R}^{21}$ is selected from the series consisting of hydrogen, $\left(\mathrm{C}_{1}-\mathrm{C}_{4}\right)$-alkyl, and $\left(\mathrm{C}_{3}-\mathrm{C}_{7}\right)-$ cycloalkyl;

$\mathrm{R}^{22}$ is selected from the series consisting of $\left(\mathrm{C}_{1}-\mathrm{C}_{4}\right)$-alkyl, $\left(\mathrm{C}_{3}-\mathrm{C}_{7}\right)-$ cycloalkyl, $-\left(\mathrm{C}_{1}-\mathrm{C}_{4}\right)-$ alkyl, and $-\left(\mathrm{C}_{3}-\mathrm{C}_{7}\right)-$ cycloalkyl; $\mathrm{R}^{23}$ and $\mathrm{R}^{24}$ are independent of one another selected from the series consisting of hydrogen and $\left(\mathrm{C}_{1}-\mathrm{C}_{4}\right)-$ alkyl;

$\mathrm{R}^{30}$ is selected from the series consisting of halogen, $\left(\mathrm{C}_{1}-\mathrm{C}_{4}\right)-$ alkyl, $-\mathrm{O}-\left(\mathrm{C}_{1}-\mathrm{C}_{4}\right)-$ alkyl, and $-\mathrm{CN}$;

Key Structures:

Recent Review Articles:

Biological Assay:<smiles>COc1ccc(Cl)c(OS(=O)(=O)c2cc(-c3ccc(NS(=O)(=O)c4cc(Cl)ccc4F)cc3)ccc2NS(=O)(=O)c2ccc(-c3cnc4c(N)n[nH]c4n3)cc2)c1</smiles>

1. Pao, A. C. SGK regulation of renal sodium transport. Curr. Opin. Nephrol. Hypertens. 2012, 21 (5), 534-540.

2. Bruhn, M. A.; Pearson, R. B.; Hannan, R. D.; Sheppard, K. E. Second AKT: the rise of SGK in cancer signaling. Growth Factors 2010, 28 (6), 394-408.

SGK-1 substrate phosphorylation inhibition assay. GSK3 $\beta$ phosphorylation inhibition in U2OS cells. 
Biological Data:

\begin{tabular}{|c|c|c|c|c|c|}
\hline Entry & \multicolumn{1}{|l|}{ SGK-1 } & GSK3 $\beta$ & Entry & SGK-1 & GSK3 $\beta$ \\
\hline & \multicolumn{2}{|c|}{$\mathrm{IC}_{50}(\mu \mathrm{M})$} & \multicolumn{2}{c|}{$\mathrm{IC}_{50}(\mu \mathrm{M})$} \\
\hline 1 & 0.003 & 1.4 & 14 & 0.003 & 2.9 \\
\hline 5 & 0.005 & 0.63 & 15 & 0.002 & 2.4 \\
\hline 6 & 0.002 & 2.1 & 16 & 0.002 & 1.5 \\
\hline 7 & 0.002 & 2.6 & 35 & 0.001 & 0.69 \\
\hline 12 & 0.004 & 1.5 & & & \\
\hline
\end{tabular}

Claims:

14 Total claims.

12 Composition claims.

2 Method of use claims.

\section{AUTHOR INFORMATION}

Corresponding Author

*Tel: 215-707-1085. E-mail: benjamin.blass@temple.edu.

Notes

The authors declare no competing financial interest. 